\title{
6 Migration control, temporal irregularity and waiting
}

\author{
Undocumented Zimbabwean \\ migrants' experiences of \\ deportability in South Africa
}

\author{
Johannes Machinya
}

\section{Introduction}

Three months before I began my fieldwork in June 2015 in eMalahleni, a coal-mining town in South Africa's Mpumalanga Province, the government had launched a major nationwide crime-fighting blitz code named Operation Fiela. 'Fiela' in Sesotho means 'sweep away,' hence the operation's aim was to sweep away crime in South Africa. The police, accompanied by the military and immigration officials, launched numerous raids across the country in neighbourhoods, taxi ranks and other places suspected of harbouring 'criminals.' However, civil society groups condemned the operation as 'state-sponsored xenophobia' (Velapi, 2015) after noting that it largely targeted 'illegal' foreign nationals as the most likely perpetrators of crime. The numbers behind the operation corroborated these claims: 1,123 of the 2,908 arrests made on July 30 and 31, 2015, countrywide were undocumented migrants; between April and July the same year, government deported over 15,000 people who were in South Africa 'illegally' (Maromo, 2015). Civil society organisations recorded several cases where foreign nationals were rounded up in pre-dawn raids, denied access to legal representation or deported without due process (Allison, 2015). The period of Operation Fiela turned into a 'moment of acute deportability' (Ellis \& Stam, 2017: p. 333), wherein increased migration enforcement repeatedly reminded undocumented migrants of their susceptibility to arrest and deportation.

In eMalahleni, police officials continued launching sporadic smaller-scale raids searching for undocumented migrants even after the end of Operation Fiela. Sometimes, the raids were dramatic, especially in Elandeni, ${ }^{1}$ an informal settlement on the outskirts of eMalahleni town, where most of the undocumented Zimbabwean migrants lived. The police would unpredictably descend on Elandeni in convoys, armed with guns, and round up undocumented migrants. Sometimes they would conduct arbitrary stop and search missions, stopping suspected migrants in the streets and other public spaces and demanding to see their passports or permits. These enforcement practices, representing what De Genova (2002: p. 436) calls 'the spectacle 
of enforcement,' constantly re-enacted undocumented migrants' sense of deportability, which is the state of living with arrest and deportation as a ubiquitous possibility, even if not actually effected (De Genova, 2002).

In this chapter, I examine how migration control in South Africa informs undocumented migrants' sense and use of time. By making the prospects of arrest and deportation more perceptible, I suggest that migration control not only accentuates undocumented migrants' sense of deportability but also plunges them into a profound state of 'temporal irregularity.' Social life, that is, social situations, events and activities, according to Zerubavel (1981), is fairly structured on the basis of time. Zerubavel has importantly highlighted four major dimensions of the temporal profile of any situation or event. First is the sequential structure of situations and events, which tells us in what order they take place. Second is their duration, which tells us how long a situation or event will last. Third is the temporal location, which designates when an event or situation will take place. And the fourth parameter is the rate of recurrence that tells us how often an event or situation (re) occurs. These parameters establish and maintain temporal regularity and thus stability in people's lives. Temporal regularity helps considerably in developing a sense of orderliness. By providing a 'highly reliable repertoire of what is expected, likely or unlikely to take place within certain temporal boundaries, [temporal regularity] adds a strong touch of predictability to the world around us ...' (Zerubavel, 1981: p. 12). Accordingly, on the other end, temporal irregularity contributes to the development of a strong sense of uncertainty.

Temporal irregularity, I suggest, is conceptually significant in studying the lived experiences of deportable migrants who are always subjected to the threat/possibility of arrest and deportation. It draws attention to how unpredictability and uncertainty both in terms of future horizon and daily routine can negatively affect migrants' well-being. In this chapter, I show that the discursive and material mobilisation of deportation by the South African state as well as its citizens drew my interlocutors into a temporal experience where they lived contemplating, fearfully, the possibility of arrest and deportation, but remained unsure when and how this would happen. I frame this temporal paradox of deportability, in which deportation was experienced as an inevitable prospect, but with no certain timeframe, as an experience of waiting whereby deportable migrants in South Africa anticipate and 'wait' for the ultimate materialisation of deportation. All of my research participants initially arrived in South Africa to look for work and imagined deportation as inevitable. This was because the country's highly selective and restrictive skills-based migration policy availed very limited opportunities for so-called 'less-skilled' migrant workers to obtain work permits or regularise their stay, making deportation their ultimate fate (Dlamini, 2019).

The undocumented migrants who participated in this study were men and women between the ages of early twenties to late forties who worked 
as domestic workers, private security guards, casual workers in the construction sector as well as daily-wage workers. Some were living with their families in eMalahleni, while others had close family members, including children, who they were financially supporting back in Zimbabwe. Through in-depth interviews and informal conversations, my interlocutors told me their experiences of encounters with migration control. There was a general consensus that migration control makes the risks and costs of mobility significantly high, producing 'processes of entrapment' (Núñez \& Heyman, 2007; Talavera et al., 2010) for undocumented migrants within the borders of South Africa. Such entrapment was not about migrants being absolutely nailed to the ground but more about how they were constricted by the high risks and costs of movement (Núñez \& Heyman, 2007).

In the sections below, I situate migration control in South Africa within existing debates on the control of migration and how migration enforcement makes deportability more palpable to undocumented migrants. I then examine how both migration policing and the heightened sense of deportability engender a temporal experience of waiting among undocumented migrants, whereby they wait for something that can happen anytime, or rather hope for something not to happen - namely, arrest and deportation. Finally, I examine how the consequences of anticipating deportation as highly likely become the central organising condition in undocumented migrants' lives.

\section{Migration control and deportability}

In response to the increased movement of people across national boundaries, migrant-receiving countries around the world have ratcheted up their efforts to control migration (Walters, 2002; Cornelius \& Tsuda, 2004). Many countries have militarised and intensified the control of border areas and surveillance of interior spaces (Nevins, 2001; Fassin, 2011), tightened restrictions on the employment and access to other services for undocumented migrants (Perea, 1997) and imposed harsher sanctions on those who defy immigration regulations (Campbell, 2006). Deportation is increasingly becoming the 'ubiquitous penalty for any immigration violation' (Stumpf, 2009: p. 1684) and a normalised practice of migration control (Bloch \& Schuster, 2005). Deportation not only forces undocumented migrants to leave a certain state territory but also propagates anxiety and terror among those who remain as not-yet-deported but facing the prospect of arrest and deportation (De Genova, 2002; Willen, 2007).

One of the objectives and functions of South Africa's migration control regime, according to the Immigration Act No. 13 of 2002, Section 2 (1)(g), is to promote 'a climate within the Republic, which encourages illegal foreigners to depart voluntarily.' The aim is to unsettle undocumented migrants through regular and systematic intimidation so that they will be forced by circumstances to leave 'voluntarily' (Klaaren \& Ramji, 2001). 
Political debates on migration in South Africa are awash with fearmongering assertions that 'illegal' migrants are flooding the country and are viewed as a major impediment to the country's ambitious agendas of political transformation, economic development and poverty alleviation (Vigneswaran, 2011). Undocumented migrants are blamed for the socio-economic malaise in the country: Unemployment, crime and poor service delivery among others (Minnaar \& Hough, 1996; Danso \& McDonald, 2001; AlfaroVelcamp \& Shaw, 2016). The then Deputy Minister of Police, Bongani Mkongi, during a press-briefing in July 2017 following his visit to Hillbrow Police Station in Johannesburg to assess issues of crime and illegal trading in Hillbrow and surrounding areas, lashed at foreigners:

How can a city in South Africa be $80 \%$ foreign nationals? That is dangerous; that in Hillbrow and surrounding areas, South Africans have surrendered their own city to the foreign nationals... if we do not debate that, that necessarily means the whole of South Africa could be $80 \%$ dominated by foreign nationals and the future president of South Africa could be a foreign national... . The arms that are being used here in Hillbrow, are arms of war which are unlicensed. The hijacking of buildings here in Hillbrow it's a sign of taking over power... by people... that we don't know... . These buildings are being hijacked by criminals.

(Lekabe, 2017)

While Bongani Mkongi's claim that $80 \%$ of the people in Hillbrow and surrounding areas were foreign migrants was dismissed as unsubstantiated according to existing data (Africa Check, 2019; Heleta, 2019), the Deputy Minister of Police portrayed undocumented migrants ('people that we don't know') as invading Hillbrow and South Africa at large. His message implied that South Africa was under attack from a foreign enemy, who put the nation and its people at risk, and, therefore, called for a fight back. His comments reflect the general sentiment across the country - citizens and some politicians have been accusing the government of failing to act decisively to stop 'illegal foreigners' from entering the country (Dodson, 2000; Crush \& McDonald, 2001; Crush \& Dodson, 2007; Tati, 2008; Vigneswaran, 2011). There has thus been an increasing call for the tightening of border controls, intensification of in-country migration control measures and deportation as the most prudent remedies to the problem of 'illegal' migration.

However, scholars have lamented that South Africa's migration control regime lacks a coherent policy framework, which has caused a disjuncture between policy in principle and practice (Vigneswaran, 2011). Vigneswaran notes that senior government officials were doubtful of the effectiveness of a control-oriented migration policy to stem the problem of 'illegal' migration. For example, in 2003, Mangosuthu Buthelezi, then minister of the department of home affairs (DHA), came to the morose conclusion that 'to think we will ever overcome the problem is a dream' (Peta, 2003; cited in: 
Vigneswaran, 2011: p. 110). Paradoxically, while policy-makers in senior government positions admitted to the failures of a control-oriented approach, policy implementers on the ground were quite active in enforcing controls, which resulted in a hard-line policy framework (Vigneswaran et al., 2010; Vigneswaran, 2011).

Police officials are thus publicly known in South Africa to invest considerable time and energy in arresting and detaining undocumented migrants. In Gauteng Province, which is the major destination for many migrants, police officers spend more than a quarter of their time at work searching for, arresting and deporting foreign nationals (Vigneswaran \& Duponchel, 2009). In that respect, Vigneswaran (2011) notes that there has been no clarity on what an alternative policy might look like. Landau (2005) has made a similar observation, noting that South Africa's migration policy tacitly creates and legitimises parallel systems of migration control that often involve exceptional, extra-legal practices in policing foreigners.

While state officials are the major actors in instituting the deportation regime, citizens have also been tasked with detecting 'illegal' foreigners. The police encourage 'community enforcement' measures that place the onus on citizens to report the presence of 'illegal' foreigners (Vigneswaran, 2011). Furthermore, until the late 1990s, the DHA even established a toll-free number and offered reward money to those who reported undocumented migrants (Klaaren \& Ramji, 2001). Landau (2005) lamented that such extra-legal policing practices license the targeting and restraining of 'illegal' foreigners by whatever means state officials and citizens deem appropriate. This, therefore, makes undocumented migrants vulnerable to vigilante 'justice' enacted by citizens, which often result in violent anti-immigrant attacks. The latest of such attacks happened at the beginning of September 2019. Such acts of vigilantism resemble the Minutemen Project in the United States of America (USA) in April 2005, which saw citizens, who were disgruntled by the failure of the US government to secure the borders against the 'millions of illegal migrants' allegedly flowing into the USA, set up 'citizen patrols' along the Arizona-Mexico border to monitor and report 'illegal' migrants (Chavez, 2007).

South Africa's control-oriented approach to migration has produced a remarkable rise in deportation numbers. Between 1995 and 2010, South Africa deported more than 150,000 people every year (Vigneswaran, 2011). From April 2009, deportations nonetheless plummeted after the DHA declared a moratorium on the deportation of Zimbabweans and launched instead a special legalisation programme - the Dispensation of Zimbabweans Project (DZP) - specifically dealing with Zimbabweans who had been in the country 'illegally.' The moratorium ended in July 2011. In the 2013-2014 reporting year, deportations rose again to over 130,000 (DHA Annual Report, 2014).

However, these policies hardly achieved the presumed goal of mass deportation; rather, while some undocumented migrants were deported, most remained un-deported subjected to the threat of deportation, that is, 
deportability (De Genova, 2002). Below I illustrate how the omnipresent prospect of deportation came to define the temporal horizons of undocumented Zimbabwean migrants in South Africa.

\section{Deportation: an inevitable but indeterminate prospect}

In eMalahleni, besides the larger nation-wide operations targeting undocumented migrants such as Operation Fiela, the more basic migration control measures include random passport inspections and police raids. These increased the chances of migrants encountering the everyday forms of police surveillance, thereby compounding the risk of arrest and making the threat of deportation more apparent. My interlocutors reported that the police often target those places where migrants are easy to find such as Isibindi Center, a shopping mall where daily-wage workers, predominantly men, congregate to be picked for a day's work, or Elandeni.

Just like the larger operations, the police conduct these more basic control measures as a spectacle. Rutendo Mutero, who worked as a live-out domestic worker and lived in Elandeni with her husband and two children, told me she has always been surprised to see armed police entering in convoys into Elandeni 'just to look for people with no papers.' Rutendo was indeed perplexed by the amount of resources and energy the police expended on searching for migrants with no papers. 'If you [were to] see them coming here,' she told me, 'you would think that they are going for a war. But they are just looking for people who have no papers.' Rutendo condemned the practices of policing migrants as affirming the stereotypes that associate 'illegal' migrants with criminality; she said: 'Precisely because when [South Africans] see [the police] coming here in their cars and with guns like that, doing what they do to us, they would just think that we are criminals.'

In another interview, Earnest Mudzviti, a daily-wage worker in his mid-forties, expressed shock at the way the police stopped migrants and demanded their passports without ascertaining whether one was a migrant or not, to the extent that he believed migrants were easily identifiable. He recounted an incident when the police stopped him and his two friends as they were walking along a road leading to Elandeni after a day's work. The police, imitating an action-movie-style raid, abruptly stopped them; before the vehicle came to a complete halt, two gun-wielding police officers jumped out of the moving car, pointed guns at them and ordered at the top of their voices: 'Show us your passports!' Earnest and his friends were stupefied by the way the police officers acted as if they had seen some dangerously armed criminals. Feeling completely helpless, he and his friends just froze, raised their hands in surrender as the police officers carelessly ransacked their pockets. Neither Earnest nor his friends had passports. The police officers eventually released them, not before taking all their earnings for that day about R550 (approximately US\$40) - and threatening them with arrest and deportation were they to catch them again not carrying their passports. 
This was not the first time Earnest was randomly stopped by the police; he told me they once stopped him in Johannesburg and asked for his passport, and again, only released him after extorting money.

The two incidents above show how the police make migration control a spectacle, which renders migrant 'illegality' spectacularly visible as an embodied signifier of difference and danger or criminality. As Rutendo remarked, this consolidates the stereotypical representation of undocumented migrants as dangerous criminals that should be dealt with violently. But more importantly, such encounters pose a major risk of arrest and detention for purposes of deportation to those migrants who have 'no papers.' Likewise, given that in such encounters the police officials' personal discretion and ultimate decision-making power is almost absolute (Vigneswaran et al., 2010), there is a huge risk of migrants losing money through extortion as Earnest and his friends' case may testify. While extortion often led to the release of the undocumented migrants from the hands of the police, they were always threatened with the promise that 'the next time' they are caught they would be arrested and deported.

The threat of arrest and deportation did not only become palpable when the migrants came in direct contact with state officials. Some migrants imagined and anticipated arrest and deportation even when they were not in the immediate clutches of migration control. Many with whom I spoke envisaged the potentiality of their arrest and deportation by drawing on or relating to stories of other 'illegal' migrants' experiences. The possibility of arrest and deportation gravitated towards reality when the undocumented migrants heard stories of the arrest and deportation of other undocumented migrants. They would begin to feel that their time is running out as well, fearing that they would be next. Rumbidzai Chikono, who worked as a liveout domestic worker, discussed how she imagined deportation as something that would also happen to her even though she had not encountered the police: 'I know about this [deportation]; it happened to others who did not have papers like me; if this happened to them, it can also happen to me.' Clearly, the stories of other undocumented migrants who have been arrested and deported were a constant reminder to those that were still un-deported that their time (to be arrested and deported) would also come.

As I mentioned earlier, South African citizens are a significant stakeholder in the deportation regime. However, they hardly play their officially sanctioned role of reporting 'illegal' foreigners to state officials (Vigneswaran, 2011); instead, they make the threats of deportation more perceptible through threatening to violently expel foreigners. As Tsitsi Shumba puts this:

With [South Africans], anytime chinogona kungo colour (tensions can escalate); they can start saying: 'We don't want to see [illegal] foreigners here; they must go back to their country.' When they start saying that then you know that it is now dangerous; you should be prepared to leave. 
Such threats are often an overture for xenophobic violence. The study participants revealed that sometimes citizens circulate the message that 'we are coming for you' to foreigners through social media platforms like WhatsApp and Facebook or other media-like flyers. The most recent occurrence took place in early September 2019. Days before the violent attacks on foreigners, Nyevero, one of the people I maintained contact with after I left eMalahleni, forwarded me a message that was circulating on WhatsApp warning of a mass shutdown and calling on South Africans 'to come together as South Africans with one voice of enough is enough, on selling of drugs, on property theft, and on our work [being] taken by foreign nationals.' The message concluded with the phrase, 'South Africa for South Africans. This is not xenophobia but the truth.' Because of these publicised threats, my interlocutors apprehensively anticipated deportation as an unpredictable, dreaded and inevitable socio-political predicament. The threats worked as a disciplinary instrument that perfectly served to remind them of their unbelonging and that their presence in South Africa will someday be terminated.

For these undocumented migrants, the threat of deportation was tremendously productive in shaping their consciousness of being 'illegal,' unwanted and deportable, as the following response shows:

We know that this [being in South Africa as an illegal foreigner] will end one day. [But] you never know when you are going to be arrested and deported. My brother, I am not a prophet, but I know that one day [we] will be chased out of this country.

(Taonga Makombe)

While Taonga's assertion elicits some degree of certainty over the imminence of undocumented migrants' expulsion from South Africa, it is also coloured with a lack of certainty over when (and how) this is likely to happen. Again, given the different actors involved in the deportation regime, the migrants were also uncertain over who would cause their expulsion - is it state officials or the generality of South African citizens?

\section{Living in a state of anticipatory preparedness}

The temporal paradox of deportability in which undocumented migrants imagined deportation as an inevitable prospect which has no certain timeframe for its actual materialisation thrust some undocumented Zimbabwean migrants into a state of anticipatory preparedness where they lived in anticipation of expulsion. Highlighting this state of anticipatory preparedness, Precious Tirivanhu, a domestic worker in her late thirties, stated that undocumented migrants 'must be prepared for anything' as they can be forced out of South Africa any day either through deportation or xenophobic violence. Being 'prepared for anything' means being vigilant and calculative of the risks and costs of remaining in South Africa. It is this anticipation and 
readiness to leave that invokes the idea of waiting as 'a sense of anticipatory preparedness - a lying-in-wait-for' (Bissell, 2007: p. 282). As the migrants wait for arrest and deportation to materialise, they also vigilantly wait for the risks and costs of remaining in South Africa to reach a certain threshold beyond which they see life in South Africa as unbearable; until then, they 'must be prepared' to leave.

The inability to accurately map or predict what would likely happen to them as the threat of deportation intensified, pressured some to leave 'voluntarily.' For example, Taonga Makombe, who I met in June 2015 after he had been in South Africa as a first-time arrival for 5 months, complained after experiencing the intense policing of migrants during Operation Fiela that: 'I can't live like a criminal, always running away from the police; this is not a life at all. I would rather suffer [in Zimbabwe] and enjoy my peace.' When I returned to eMalahleni in August 2015, I was told that he had indeed 'packed his bags' and returned to Zimbabwe. For Taonga, being always on the lookout for the police and unable to know what would happen forced him to 'choose' to return to Zimbabwe. Deportability placed Taonga in a state of complete uncertainty, confirming Bourdieu's (2000: p. 228) observation that absolute power places others 'in total uncertainty by offering no scope to their capacity to predict.'

For those who remained in South Africa, the constant threats of arrest and deportation, and xenophobic attacks discouraged them from making any durable investments in Elandeni as Beulah's case aptly demonstrates. When I visited her for the first time in 2015, she took me to her home, a single-roomed shack built on a cement slab with loosely joined and rusty corrugated iron sheets. The gaps in the walls were stuffed with rags to block wind and dust, which made the room poorly lit. Inside was a visibly old double bed on one side of the walls and piled in a corner were two large suitcases. In the opposite side of the bed was the kitchen. Offering me a 20 -litre plastic bucket and desperate to make me understand why she was living under such poor conditions, Beulah said:

Your niece has no chair in the house uncle; you have to sit on this bucket. Tiri vana Mugaradzakasungwa ([It's because] we are people who live with bags packed.) We don't know what can happen, anytime things can escalate and we will be chased out.

I turned the bucket upside down and sat behind the half-opened door.

Living in a scantily furnished house in an informal settlement, with bags packed, demonstrated Beulah's preparedness to leave, and is an important trope signifying the life of people who, when things escalate, were ever-ready to 'pick up' their bags and leave. Beulah did not have many possessions in her house because, due to the threat of expulsion, the possibility of longterm settlement remained uncertain. Having a chair in such circumstances would imply a relaxed lifestyle, which was far from real for her and the other 
undocumented migrants. The understanding that at any time they could be forced to leave South Africa forced Beulah to tolerate a life of discomfort. This did not mean she distasted living comfortably; instead, she feared that in the event of deportation, she would lose her property.

Indeed, previous research on the deportation of undocumented migrants from South Africa found that migrants are not usually given the chance to take their possessions during deportation (Human Rights Watch, 2007). The fear of losing possessions during the process of deportation caused Beulah to defer the possibility of a comfortable life to her probable return to Zimbabwe. She saw her present lifestyle of discomfort and squalor in South Africa as temporary. Despite living in an informal settlement and sleeping on a torn old bed, Beulah boasted that in Zimbabwe, she has already built for herself a two-bedroom house furnished with a comfortable bed. She was now saving money to buy sofas to send home. So, the life she lived in Elandeni suited her condition of being deportable and she summed it by saying 'Izvi ndezvekuno' (This [life of discomfort] is just for the meantime, while we are here.)

\section{Just waiting?}

The perceived inevitability of deportation, and fear thereof, created some form of existential hiatus which some of my interlocutors captured in the phrase 'we are [now] just waiting... .' Due to the ever-present threat of deportation that was re-enacted through the everyday practices of migration control, Sam Tizora felt that remaining un-deported 'does not help at all because we are going to be chased out anyway.' Donald Mutsvedu, who was working as a security guard, recounted how the police had intensified migration control in the name of fighting crime and said: 'Now we are just waiting to be chased out of the country.' Sam and Donald lived their lives in a narrowly circumscribed present where they lived 'just' waiting for their fate. For them, 'just waiting' was a discursive way of underlining their heightened sense of vulnerability to deportation based on feelings of being unwanted, which strengthened their experiences of deportability.

Donald's statement that 'We are [now] just waiting ...' thus evokes a state of total resignation to fate wherein he was expecting his ultimate deportation while time just passed by. Such form of waiting, as a subjective experience of undocumented migrants' time in South Africa, suggests an interval of suspension or pause in action while waiting for the actual deportation to happen. In other writings on waiting, the time of anticipation is similarly portrayed as 'sitting' and/or 'doing nothing' (Tirado, 2018); or useless, wasted time (Schweizer, 2008). This suggests that the lives of people in waiting are put 'on hold' (Bloch, 2014) - they just (sit and) wait.

However, as Jacobsen and Karlsen highlighted in the introduction to this book, the idea of conceptualising waiting as a temporal disjuncture has some analytical deficits. This is so because, I suggest, beyond the narrative of 'living with our bags packed [and waiting]' and 'just [sitting and] waiting,' 
my interlocutors were hardly trapped in a temporal fixity where they just 'sit,' 'do nothing' and wait. The idea of 'just waiting' leaves one wondering what waiting is and uncovers how difficult it is to delimit the temporal boundaries of where waiting begins and ends. Importantly, the assumed empty time of waiting was brimming with activity; the deportable migrants were not in fact 'just [sitting and] waiting.' Rather, they were involved in different activities such as working or looking for work during the week, as well as in various social activities such as attending church services on weekends.

The understanding that anytime one could be arrested and deported, left my interlocutors feeling as if they were living off borrowed time; that they had no more time left to remain in South Africa. This strongly incentivised some of them to maximise their time. They saw the time of their precarious presence as a precious resource that ought to be used productively. Tsitsi Shumba worried about this:

Every day I pray to God that we can be here (in South Africa) for a little longer; my child is still in school in Zimbabwe. How will I pay for his fees if I am deported?

Because of her parental responsibilities, Tsitsi wished her deportation would only happen in the far future. For Tsitsi, the threat of deportation made her treasure her time before the 'inevitable' manifestation of deportation and wished for actual deportation to be delayed. Remaining un-deported prolonged the time to work and be able to accrue more, albeit under uncertain and exploitative conditions. For this reason, Tsitsi prayed thanking God for protection every day when she reached home safely from work without getting into trouble with the police.

While it appears difficult to mark the boundaries between the beginning and ending of waiting, scholars have underscored a common characteristic of waiting; it is an ambivalent time and space, an 'in between' (Sutton et al., 2011). This means that there is always a 'before' and an 'after' in relation to waiting, which implies linear time (waiting for the arrival or fulfilment of the object being waited for). For deportable migrants, their waiting time sits between the time before their potential apprehension and the time after their eventual deportation; hence Donald Mutsvedu's remark that '...we are just waiting to be chased out of the country,' meaning their time of waiting ends with their deportation. While the migrants revealed that those who get deported may be able to re-enter 'illegally,' the costs of re-entry may be so high that it could be delayed as one tries to raise enough money, or completely abandoned if one fails to raise the necessary funds.

Turner (1983: p. 308) hypothesised that prolonged experiences of waiting 'lead to a declining sense of urgency and correspondingly reduced vigilance and preparedness.' This hypothesis predicts no loss of conviction that the object being waited for would eventually come; instead, people just become less vigilant. This is also true for some undocumented migrants who had 
lived in a palpable sense of deportability for a long time; their fear that is incited by the threat of deportation had reached a point of saturation, and as such, they cared less about the possibility of deportation. In fact, many had mastered the art of avoiding detection and arrest. Sthabile Mnyulwa, who had been in South Africa since 2005, said she was now less afraid of the police because she could mask her foreignness and 'illegality.' 'I'm not afraid of them anymore,' she told me. 'I now speak Zulu fluently and if they stop me, they will think I am a South African.' Indeed, I met some undocumented Zimbabweans whom, before I was told were Zimbabweans, I had initially mistaken them for South African citizens.

\section{Temporal irregularity and uncertainty in everyday life}

So far, I noted that undocumented migrants' experiences of deportability lacked a fixed temporal specificity, which is a specific timeframe or precise deadline as a promise for the actual materialisation of the event being waited for - arrest and deportation. Rather, deportability subjected the migrants to a state of indefinite waiting; it could either be very long, or there could be a sudden dramatic end to one's time of being present in South Africa. The ever-present threat of deportation and migrants' inability to predict when arrest and deportation would materialise made such waiting a period of uncertainty as attested by Rumbidzai Chikono: 'Sometimes you go to work, but you don't know whether you will come back or not. You can be arrested anytime.' Migration control practices made life for many undocumented migrants a game of hide-and-seek with the police, in which the stakes were high. Arrest could result in deportation or extortion of money.

The urgency to want to make the best of their time in South Africa compelled many to work as hard and as long as possible no matter the conditions of employment; some even doing multiple jobs. Oliver Chiororo, James Mago and Tobby Murazvo all had incredibly difficult work arrangements, working double shifts each day. At night they worked as security guards and during the day they worked as 'contracas' (contract workers) in construction. For these men, their daily routines of work and home time were not as rigid as other people, who moved regularly from their homes to the workplaces and back. Instead, they juggled between different jobs every day with little or no time to rest because, according to Oliver, they had 'no time to waste.'

Sometimes unpredictable encounters with migration control completely disrupted the socio-temporal order in undocumented migrants' daily lives; they would fail to do what they expected within certain temporal boundaries. For example, David Gomo and Temba Mhuru, who worked for a subcontracted construction company, were unexpectedly stopped on their way to work by police officer, who then demanded their passports, which they did not possess; neither did they have money to bribe the officers for their freedom. The police consequently locked them in the back of the police van and drove with them around eMalahleni. When the police officers finally stopped, 
the two men pleaded to be released. The police released them, but not before taking, or in the words of David, 'wasting' a greater part of their time.

Vigneswaran et al. (2010), writing on the informal migration control practices by the police in South Africa, note that not all encounters between undocumented migrants and the police resulted in the arrest of the undocumented migrants. The police regularly bend the immigration laws in their own favour, but also often do so to benefit the undocumented migrants who may escape arrest if they were sufficiently 'congenial,' 'respectful' or 'obedient' (Ibid). David and Temba were expecting to get to their workplace by half past seven in the morning, but they arrived very late that day after their close brush with migration control.

The threat and fear of deportation resulted in some undocumented Zimbabwean migrants redefining the meaning of work. They ceased to solely see work as a vehicle for goal attainment. Despite the possibility of workplace raids, some migrants saw work or being in a work environment as a shield against possible encounters with the police. Those who were not working and spent much of their daytime in Elandeni felt caged and vulnerable to police arrest. When Rutendo Mutero first came to South Africa, she had no intentions of doing wage-work because her husband was working and providing for the family. She was doing the unpaid childcare at home. However, some time in 2015, the police raided Elandeni searching for 'illegal' foreigners. Rutendo was arrested while sitting outside her home and she spent 12 days in police custody with her toddler. She went to court and was fined R500 (approximately US\$40). She was then ordered to leave the country. After her release, however, Rutendo immediately began looking for a job as a live-out domestic worker. That was so because she felt it was safer to spend the day working in someone's house than being in Elandeni. For her, working was just a way of keeping herself away from the menacing presence of the police in Elandeni. In much the same way as Willen (2007) analysed how migrants' homes in Tel Aviv lost their role as safe havens during Israel's deportation campaign in mid-2002, Rutendo's story indicates the penetrability of 'illegality' in the home and the porousness of the home to immigration enforcement. Other undocumented migrants shared Rutendo's sentiments that it was safer to spend the day at work and come home in the evening as the police conducted most of their operations during the day when most people were at work.

\section{Conclusion}

This chapter examined the effect of migration control in South Africa on undocumented migrants' sense and use of time. I argued that migration control, by subjecting undocumented migrants to the threat/possibility of deportation, drives them into a state of temporal irregularity in which they remain uncertain about the exact temporal juncture at which they will face arrest and deportation. The threat of arrest and deportation continuously 
reminds undocumented migrants that their time in South Africa is in fact ephemeral and could be terminated any day. This evokes a temporal experience in which the undocumented migrants anxiously anticipate arrest and deportation as an inevitable prospect. I framed this as an experience of waiting. The concept of temporal irregularity is deployed in this chapter to analyse how the arbitrariness of migration control disrupts the sociotemporal order in the lives of undocumented migrants. Here I followed Zerubavel (1981), who argued that temporal irregularity contributes to the development of a strong sense of uncertainty.

Temporal irregularity in the lives of undocumented migrants is primarily a result of the contradictions in South Africa's migration policy formulation and policy implementation regarding the effectiveness of a control-oriented approach in solving the 'problem' of 'illegal' migration. This has opened gaps for opportunism and invention particularly among the lower and local level state functionaries like the police. What this means is that immigration law enforcement is left to the discretion of the officials on the ground. Oftentimes, the police officials bent the laws in their favour for their own personal gain (Vigneswaran et al., 2010). The situation is made worse by the fact that South African citizens are also a powerful stakeholder with informal deporting powers to enforce migration control. This leaves undocumented migrants more vulnerable to abuse and creates a lot more uncertainty in their encounters with the regime of migration control. Because the threat of expulsion is constantly re-enacted in their lives, either through the threats of arrest and deportation by the police or threats of violent expulsion by the citizens, the undocumented migrants cannot determine with certainty what will likely happen to them within certain temporal boundaries, or how long they will likely remain in South Africa. This temporal uncertainty adversely affects their everyday lives to the extent that most of them live with a sense of anticipatory preparedness (waiting) for their ultimate fate.

\section{Acknowledgements}

The article benefited immensely from the mentorship of my PhD supervisors, Prof. Bridget Kenny and Prof. Shireen Ally. I am also grateful to the editors of the WAIT book project, Christine M. Jacobsen, Marry-Anne Karlsen and Shahram Khosravi, for their insightful comments and feedback on earlier drafts. This study was generously supported through the Andrew W. Mellon Foundation Doctoral Bursary (2014-2018) in the Wits History Workshop's Local Histories and Present Realities research programme at the University of the Witwatersrand.

\section{Note}

1 I use pseudonyms for all the names of places and participants, except for eMalahleni, which is the study area. 


\section{References}

Africa Check. (2019) Unproven that Hillbrow, nearby areas are ' $80 \%$ foreign national' as claimed in much-shared video. Polity, 4 September 2019. Available from: https://www.polity.org.za/print-version/unproven-that-hillbrow-nearbyareas-are-80-foreign-national-as-claimed-in-much-shared-video-2019-09-04. (accessed 22 October 2019).

Alfaro-Velcamp, T. \& Shaw, M. (2016) 'Please GO HOME and BUILD Africa:' Criminalising immigrants in South Africa. Journal of Southern African Studies. 42 (5), 983-998. DOI: 10.1080/03057070.2016.1211805.

Allison, S. (2015) Attacks on migrants show failure to stem racial tension. Mail and Guardian, 10 November. Available from: https://mg.co.za/article/2015-11-10attacks-on-migrants-show-failure-to-stem-racial-tension. (accessed 16 February 2016).

Bissell, D. (2007) Animating suspension: Waiting for mobilities. Mobilities. 2 (2), 277-298. DOI: 10.1080/17450100701381581.

Bloch, A. (2014) Living in fear: Rejected asylum seekers living as irregular migrants in England. Journal of Ethnic and Migration Studies. 40 (10), 1507-1525. DOI: 10.1080/1369183X.2013.859070.

Bloch, A. \& Schuster, L. (2005) At the extremes of exclusion: Deportation, detention and dispersal. Ethnic and Racial Studies. 28 (3), 491-512. DOI: 10.1080/ 0141987042000337858.

Bourdieu, P. (2000) Pascalian meditations. Chicago, IL, Stanford University Press.

Campbell, E.K. (2006) Reflections on illegal immigration in Botswana and South Africa. African Population Studies. 21 (2), 1-23. DOI: 10.11564/21-2-340.

Chavez, L.R. (2007). Spectacle in the desert: The Minuteman Project on the U.S-Mexico border. In: Pratten, D. \& Sen, P. (eds.) Global vigilantes: Anthropological perspectives on justice and violence. New York, Columbia University Press, pp. $25-46$.

Cornelius, W.A. \& Tsuda, T. (2004) Controlling immigration : The limits of government intervention. In: Cornelius, W.A., Tsuda, T., Martin, P.L. \& Hollifield, J.F. (eds.) Controlling immigration: A global perspective (2nd ed.). Stanford, CA, Stanford University Press, pp. 3-48.

Crush, J. \& Dodson, B. (2007) Another lost decade: The failures of South Africa's post-Apartheid migration policy. Journal of Economic and Social Geography. 98 (4), 436-454. DOI: 10.1111/j.1467-9663.2007.00413.x.

Crush, J. \& McDonald, D.A. (2001) Introduction to special issue: Evaluating South African immigration policy after apartheid. Africa Today. 48 (3), 1-13. DOI: 10.1353/at.2001.0048.

Danso, R. \& McDonald, D.A. (2001) Writing xenophobia: Immigration and the print media in post-apartheid South Africa. Africa Today. 48 (3), 115-137. DOI: 10.1353/at.2001.0050.

De Genova, N.P. (2002) Migrant 'illegality' and deportability in everyday life. Annual Review of Anthropology. 31, 419-447. DOI:10.1146/annurev.anthro.31. 040402.085432 .

Department of Home Affairs Annual Reports. (2014) Available from: http://www. dha.gov.za/index.php/about-us/annual-reports. (accessed 2 September 2016).

Dlamini, P. (2019) SA no place for unskilled foreigners. Sowetan Live, 27 September. Available from: https://www.sowetanlive.co.za/news/south-africa/ 
2019-09-27-sa-no-place-for-unskilled-foreigners/?fbclid=IwAR0_DTmjprqoQ8wwSSYczOva-j4WMFvTZlpW0e9MVC9D-GCOQCziYttBow. (accessed 4 October 2019).

Dodson, B. (2000) Porous borders: Gender and migration in Southern Africa. South African Geographical Journal. 82 (1), 40-46. DOI: 10.1080/03736245.2000.9713683.

Ellis, B.D. \& Stam, H.J. (2017) Cycles of deportability: Threats, fears, and the agency of 'irregular' migrants in Canada. Migration Studies. 6 (3), 1-24. DOI: 10.1093/migration/mnx049.

Fassin, D. (2011) Policing borders, producing boundaries: The governmentality of immigration in dark times. Annual Review of Anthropology. 40 (1), 213-226. DOI: 10.1146/annurev-anthro-081309-145847.

Heleta, S. (2019) Xenophobia and party politics in South Africa. Mail and Guardian. 3 September. Available from: https://mg.co.za/article/2019-09-03-00-xenophobiaand-party-politics-in-south-africa. (accessed 9 September 2019).

Human Rights Watch. (2007) "Keep your head down”: Unprotected migrants in South Africa. New York, Human Rights Watch.

Klaaren, J., \& Ramji, J. (2001) Inside illegality: Migration policing in South Africa after apartheid. Africa Today. 48 (3), 35-47.

Landau, L.B. (2005) Immigration and the state of exception: Security and sovereignty in East and Southern Africa. Millennium: Journal of International Studies. 34 (2), 325-348. DOI: 10.1177/03058298060340021201.

Lekabe, T. (2017) Mbalula's deputy accuses foreign nationals in Hillbrow of economic sabotage. The Citizen, 14 July. Available from: https:/citizen.co.za/news/ south-africa/1574446/mbalulas-deputy-accuses-foreign-nationals-of-economicsabotage-spouts-alternative-facts/. (accessed 2 August 2017).

Maromo, J. (2015) The numbers behind Operation Fiela. Mail and Guardian, 7 September. Available from: https://mg.co.za/article/2015-09-07-the-numbersbehind-operation-fiela. (accessed 24 May 2016).

Minnaar, A. \& Hough, M. (1996) Who goes there? Perspectives on clandestine migration and illegal aliens in Southern Africa. Pretoria, Human Sciences Research Council.

Nevins, J. (2001) Operation gatekeeper: The rise of the "illegal alien" and the remaking of the U.S. - Mexico boundary. New York, Routledge.

Núñez, G.G. \& Heyman, J.M. (2007) Entrapment processes and immigrant communities in a time of heightened border vigilance. Human Organization. 66 (4), 354-365. DOI: 10.17730/humo.66.4.v32mp32167k81705.

Perea, J.F. (1997) Immigrants out! The new nativism and the anti-immigrant impulse in the United States. New York, New York University Press.

Schweizer, H. (2008) On waiting. London, Routledge.

Stumpf, J. (2009) Fitting punishment. Washington and Lee Law Review. 66 (4), $1683-1741$.

Sutton, R., Vigneswaran, D. \& Wels, H. (2011) Waiting in liminal space: Migrants' queuing for Home Affairs in South Africa. Anthropology Southern Africa. 34 (1-2), 30-37. DOI: 10.1080/23323256.2011.11500006.

Talavera, V., Núñez-Mchiri, G.G. \& Heyman, J.M. (2010) Deportation in the US-Mexico borderlands: Anticipation, experience, and memory. In De Genova, N.P. \& Peutz, N.(eds.) The deportation regime: Sovereignty, space, and the freedom of movement. Durham, Duke University Press, pp. 166-195. 


\section{Johannes Machinya}

Tati, G. (2008) The immigration issues in the post-apartheid South Africa: Discourses, policies and social repercussions. Space Populations Societies. 3, 423-440. DOI: 10.4000/eps.3496.

Tirado, D.I. (2018) 'We sit and wait:' Migration, mobility and temporality in Guliston, Southern Tajikistan. Current Sociology Monograph. 67 (2), 315-333. DOI: 10.1177/0011392118792923.

Turner, R.H. 1983. Waiting for disaster: Changing reactions to earthquake forecasts in Southern California. International Journal of Mass Emergencies and Disasters. 1 (2), 307-334.

Velapi, M. (2015) Civil society groups condemn 'Operation Fiela.' Elitsha. 1 June. Available from: http://wwmp.org.za/elitsha/2015/06/01/civil-society-groupscondemn-operation-fiela/. (16 February 2016).

Vigneswaran, D. (2008) Enduring territoriality: South African immigration control. Political Geography. 27, 783-801. DOI: 10.1016/j.polgeo.2008.10.003.

Vigneswaran, D. (2011) Migration control, documentation, and state transformation. In: Wa Kabwe-Segatti, A. \& Landau, L.B. (eds.) Contemporary migration to South Africa: A regional development issue. Washington, The International bank for Reconstruction and Development, pp. 106-119.

Vigneswaran, D., Araia, T., Hoag, C. \& Tshabalala, X. (2010) Criminality or monopoly? Informal immigration enforcement in South Africa. Journal of Southern African Studies. 36 (2), pp. 465-481. DOI: 10.1080/03057070.2010.485797.

Vigneswaran, D. \& Duponchel, M. (2009) One burden too many? A cost-benefit analysis of immigration policing in Gauteng. Forced Migration Studies Programme, University of the Witwatersrand, Johannesburg.

Walters, M. (2002) Deportation, expulsion, and the international police of aliens. Citizenship Studies. 6 (3), 265-292. DOI: 10.1080/1362102022000011612.

Willen, S.S. (2007) Toward a critical phenomenology of 'illegality:' State power, criminalization, and abjectivity among undocumented migrant workers in Tel Aviv, Israel." International Migration. 45 (3), 8-38. DOI: 10.1111/j.1468-2435.2007.00409.x.

Zerubavel, E. (1981) Hidden rhythms: Schedules and calendars in social life. Berkeley, University of California Press. 